\title{
THE FINAL PALAEOLITHIC IN THE COASTAL PART OF LITHUANIA WITH THE TECHNOLOGICAL EMPHASIS ON AUKŠTUMALA STONE AGE SITES
}

\section{TOMAS RIMKUS, ${ }^{1 *}$ ALGIRDAS GIRININKAS ${ }^{1}$}

\author{
${ }^{1}$ Institute of Baltic Region History and Archaeology, Klaipeda University, Herkaus Manto St 84, LT-92294, Klaipeda, Lithuania
}

\section{Keywords}

Swiderian culture, lithic technology, tanged points, willow leaf-shape points, non-flint rocks, Final Palaeolithic, coastal Lithuania

\begin{abstract}
The Final Palaeolithic in the Lithuanian coastal zone has so far been represented only by a few archaeological finds from individual contexts, and a small number of archaeological excavations. However, their analysis has not revealed much regarding the technological development of hunting implements and work tools, or the choice and the use of necessary raw materials, and little data has been provided on the chronological aspects, or the connection between settlement locations and the changing level of the Baltic Sea. This paper presents the latest archaeological material from the Final Palaeolithic in the Lithuanian coastal area, based on the three sites at Aukštumala upland bog, and stray finds found in the area. The article focuses on technological and typological aspects of lithics related to Swiderian culture. The results of the study show that, with the shortage of flint raw material, Final Palaeolithic societies at Aukštumala relied on smaller and narrower blades, and compensated for the lack of flint raw material by using other, locally available metamorphic rocks.
\end{abstract}

\section{Introduction}

After the Last Glacial, the shores of the east Baltic underwent numerous changes in the sea level over the past circa 12,000 years. This is evidenced by the Early Holocene Pinus sub-fossil forest remains beneath 11 to 27-metredeep water, as well as by the Mesolithic man-made tools washed up on to the coast of Lithuania (Žulkus and Girininkas 2012; 2014; 2020; Žulkus et al. 2015; Rimkus 2019; Danusevičius et al. 2021). These changes, and the complicated formation of coastal rivers and lakes, have made locating Late Glacial and Early Holocene sites of human habitation in the area in question complex. There are currently only a few places yielding typical Late Mesolithic to Early Neolithic bone, antler and amber assemblages; however, most of them (e.g. the former Bachmann manor, Smelte and Palanga) consist of stray finds, or come from sites that are now considered destroyed (e.g. Rimantienè 1992; Girininkas 2011; Piličiauskas et al. 2015; Rimkus
2018; 2019). The first two Stone Age sites at Aukštumala upland bog (the area around the River Nemunas delta, the southern part of the Lithuanian coast) were found excavated in 2004. Forty-five worked flints suggest Final Palaeolithic to Mesolithic habitation sites (Dakanis 2006); but further field investigations were not performed to improve the site chronology. The technological analysis of one arrowpoint and backed piece, as well as of other lithics, suggests that its cultural affiliation should be considered as Ahrensburgian and Middle Mesolithic Neman cultures (Grigaliūnas 2013; Slah 2013); however, after the technological re-investigation of the excavated material, some of the previous hypothesis should be treated as unreliable. Nevertheless, the sites at Aukštumala demonstrate a huge potential for future investigations into the earliest settlement on the east Baltic coast.

In 2018 and 2019, new excavations of the Aukštumala Stone Age sites started, within the framework of a research

* Corresponding author. E-mail: tomas.rimkus@ku.lt 


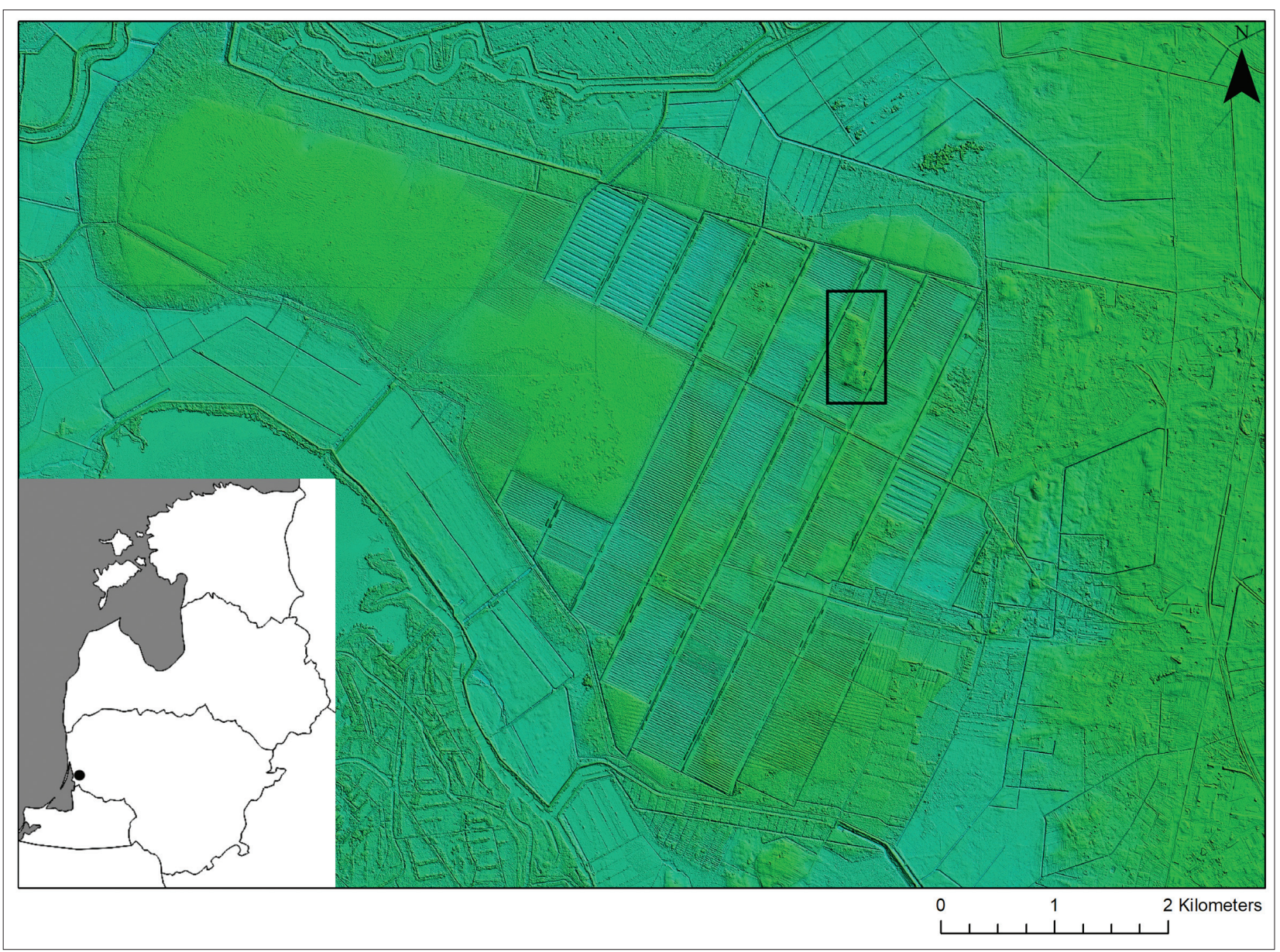

Figure 1. The location of Aukštumala bog, with the area of the fluvio-glacial hill marked.

project regarding the earliest settlement by prehistoric societies on the Lithuanian coast. An area of 84 square metres was investigated, and samples were taken for palaeobotanical and geochemical analysis, and for AMS ${ }^{14} \mathrm{C}$ dating. The newly discovered lithic technological analysis showed that all three sites at Aukštumala should now be regarded as a place of habitation of Final Palaeolithic Swiderian culture, and it should be understood as the earliest habitation site on the current coast of Lithuania. This paper presents the first results of the latest investigations at Aukštumala upland bog, concentrating on lithic technology and its implications for Final Palaeolithic huntergatherer societies in coastal Lithuania.

\section{Research background}

Aukštumala upland bog is situated in the southern part of the Lithuanian coast, in the Nemunas delta area (Fig. 1). It is the largest upland bog in the lowlands of the Lithuanian coast. The bog itself is divided into two separate sections: the western part has been a nature reserve protecting the natural environment of the bog since 1995; whereas the eastern part is given over to commercial peat extraction. Peat digging at Aukštumala bog started as early as 1882, when peat was extracted manually in an undrained environment. Only in 1968 did modern peat extraction in the eastern part of the moor start, and it has continued until today. Old maps of the bog demonstrate several major hilly areas, which were possibly former islands. However, most were destroyed during the peat extraction, but one fluvio-glacial hill ( $\left.55^{\circ} 39^{\prime} 23^{\prime} \mathrm{N}, 21^{\circ} 41^{\prime} 57^{\prime} \mathrm{E}\right)$, which lies in the middle of the peat extraction area, contains the remains of three Stone Age sites, and is the main subject of this paper (Fig. 2).

At the end of the 19th century, the Aukštumala upland bog became one of the best-studied wetlands in northern Europe. The first natural research on the wetland was carried out there by the German researcher C.A. Weber, who in July and August 1898 carried out detailed research throughout the Aukštumala wetland (Weber 1902). He returned again late in the summer of 1900. Following his fieldwork, Weber (1902) published a study on wetland vegetation, which is said to be the first detailed study in European upland bog studies ${ }^{1}$. However, the first data about possible archaeological sites in the bog comes from

1 Thanks to the Lithuanian Fund for Nature, C.A. Weber's study of Aukštumala upland bog was also published in Lithuanian in 2016 (Weber 2016). 


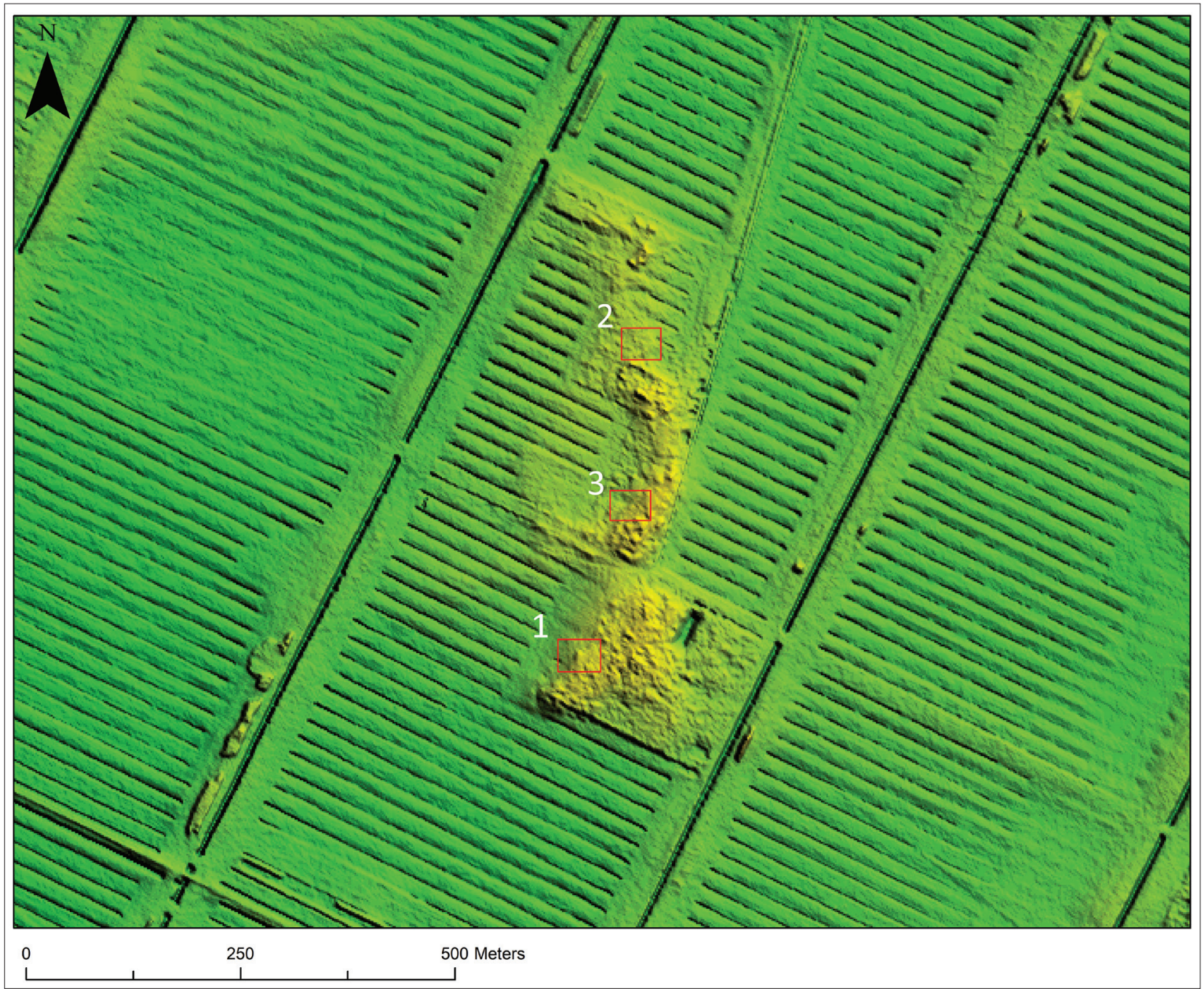

Figure 2. The locations of Aukštumala sites 1,2 and 3.

the fieldwork by the German researcher A. Bezzenberger, who in 1891 conducted small-scale excavations in the eastern part of the bog. Bezzenberger concentrated on the prehistoric archaeology of East Prussia, and thanks to his field studies, many stray finds, Neolithic sites and Iron Age burial grounds are known in the area (Tamulynas 1998; Rimantiené 1999). Bezzenberger's research interest in Aukštumala bog was stimulated by locals, who called one of the sandy hills in the eastern part of the bog Pilskalnis, which means 'hillfort'. It is also important to mention that the hill and its surroundings were also called 'fox hill. This name was used over the centuries, and is even used today. In 1891, with the support of the local landowner and amateur archaeologists E. Scheu, Bezzenberger undertook the first archaeological excavations in the socalled hillfort; however, besides charcoal, large boulders and wood, no archaeological finds, nor any indications of former fortifications or a settlement site, were found (Bezzenberger 1892). According to Bezzenberger (1892), the hill was approximately 2.5 metres high above the surface of the ground at that time. It is obvious that Weber was also familiar with the excavation site. During his bog studies, he conducted several cores around the hill, and even test-pitted the hill itself in order to examine its stratigraphy. He later described the upper layers as consisting of various types of peat characteristic of upland bogs, and only in the deeper layers was fluvio-glacial sand reached (Weber 1902). According to his data, the test pit on the hill should have been approximately 1.4 metres deep, and Weber noted that by that time the hill was almost six metres above the level of the Curonian Lagoon. Nevertheless, he did not mention any archaeological finds during his field studies, although he was acquainted with archaeological studies very well. This can be proven by his collaboration with the famous German archaeologist J. Mestorf in the Kiel fjord, where they both studied Stone Age sites, and Weber took samples for palaeobotanical studies (Weber and Mestorf 1904).

Nevertheless, despite the not so successful results of Bezzenberger's excavations, the hillfort of Aukštumala upland bog was later referred to several times by other German 
researchers (Hollack 1908; Crome 1938), and Lithuanian archaeologists (Tarasenka 1928; Tautavičius 1975), and it is even included in the latest volume of the 'Atlas of Lithuanian Hillforts' (Baubonis et al. 2017, pp. 16-17). The next archaeological visit to the sandy hill is mentioned only in 1972, when archaeologists surveyed the area of the socalled hillfort. However, during their visit, it became clear that in 1968 and 1969, the entire hill was excavated, and the sand was used to prepare the road to the peat extraction area. Nonetheless, in 1973 it was decided to protect the remains of the sandy hill, and the area was included in the list of Lithuanian cultural monuments. A further visit took place in 1984, the protected area was fixed, and finally in 1998 it was included on the list of the protected state heritage. During this visit, the archaeologist B. Dakanis found flints on the surface, and suggested calling the place a possible Stone Age site (Dakanis 2006). In 2004, the area was threatened by the expansion of the peat extraction fields, and a need emerged to conduct rescue excavations. During the archaeological fieldwork, more than 100 square metres were excavated in the sandy part of the area. The excavations were carried out mostly by test pits, and in ten-square-metre areas. Two major concentrations of lithic assemblages were located: one in the southern part of the island (site 1), and one in the north (site 2). The areas were mapped and included on the list of the protected state heritage. Despite the size of the area studied, the lithic assemblage consisted of a small number of flint finds. However, it included several typologically distinctive tools, such as a dihedral burin, scrapers, a perforator and a fragment of a willow leaf-shape arrowhead, which suggest the possible chronology of the sites. It was immediately assumed that the sites belong to the Final Palaeolithic and Mesolithic (Dakanis 2006). It is worth mentioning that during the field studies, no traces of a former hillfort or any fortifications were found.

The material from the 2004 excavations was first published only in 2013. The typological and technological analysis of the lithics did not change the previously assumed chronology (Dakanis 2006); however, it assigned the sites to Final Palaeolithic Ahrensburgian and Middle Mesolithic Neman cultures (Grigaliūnas 2013). New excavations at the Aukštumala Stone Age sites were planned for the summer of 2018, and before it a critical view was shed on the previous interpretation of taxonomy, as a fragment of a point indicated the possible willow leaf-shape arrowhead technology of Swiderian technology, rather than Ahrensburgian. The latest excavations and its material have enabled us to shed a new light on the Aukštumala bog sites, their place in the earliest occupation of the present coast of the east Baltic, and the lithic technology used at the sites.

\section{Materials and methods}

\section{Archaeological excavations}

A total of 84 square metres was excavated in the fluvioglacial hill between 2018 and 2019 (Rimkus and Girininkas 2019; 2020). The excavations were concentrated on sites known before; therefore, 40 square metres were excavated at site 1 , and ten square metres were excavated at site 2. The rest of the test pits were concentrated in the most promising locations on the sandy hill to locate new sites. The test pits yielded results, and a new Stone Age site, named site 3 , was discovered in the middle between site 1 and site 2. An area of 20 square metres was excavated in this location. All the excavation areas were located on the edges of the sandy hill, close to the peat fields. No features were discovered during the excavations; however, that could be due to the small excavation area, or more possibly to the post-depositional disturbances caused by the extensive peat extraction in the adjacent peat fields.

\section{AMS ${ }^{14} \mathrm{C}$ dating}

All the excavated areas at Aukštumala are sandy-type open-air sites. This type of prehistoric site usually contains mixed materials, from at least several episodes of occupation. However, all the sites at Aukštumala contained homogenous lithic material, with no technological admixture from later periods. Therefore, organic samples of wood charcoal and charred hazelnut shells found in the same yellowish sand layers as the lithic finds were sampled for Accelerated Mass Spectrometry (AMS) radiocarbon dating. Four organic samples were dated at the Leibniz Laboratory for Radiometric Dating and Stable Isotope Research at Kiel University. The dates were calibrated by OxCal v4.4 (Bronk Ramsey 2017) and the IntCal20 atmospheric curve (Reimer et al. 2020).

\section{Lithic studies}

A total of 311 lithic finds were found at Aukštumala sites 1, 2 and 3 during the fieldwork in 2018 and 2019. The finds constituted flint and various metamorphic rocks, including knapping waste and tool manufacturing debris, as well as tools and pieces of them. The typology and technology of the lithic finds discovered at Aukštumala sites 1 and 2 in 2004 have already been discussed by Grigaliūnas (2013). However, after the re-investigation of these lithics, and with the addition of new material from the 2018 and 2019 excavations, some of the previous suggestions should be revised, and a new technological interpretation is presented in this paper. Therefore, we include some of the previously discussed lithics in the analysis. 
One of the distinguishing features of Swiderian culture lithic technology is tanged and willow leaf-shaped points, on which basis the lithic complex can be attributed to a specific technology and the implied chronology (e.g. BergHansen et al. 2019a; Serwatka 2018; Winkler 2019). However, the technology of the Swiderians has been examined in recent years, paying much more attention to the methods of core preparation and their exploitation, as well as blade morphology (e.g. Berg-Hansen et al. 2019b; Grużdź 2018; Pyżewicz et al. 2019; Gudaitienè 2020). During the fieldwork at the Aukštumala sites in 2018 and 2019, only one flint core was found which was completely exhausted. Therefore, it is difficult to speculate about the technique of the preparation of the cores. In 2018 and 2019, and including the 2004 fieldwork, over 50 blades were discovered at all three sites; however, most of them are only fragments. Therefore, this paper focuses only on full or almost completely preserved blade fragments, in which it would be possible to see the morphology of the bulb, the curvature, the negative number, and the remnants of the core platform and other features. In addition to this data, the blades were measured, and their length, width and thickness are given, which supplements the tendencies in blade technology.

In most Stone Age settlements, raw material of other rocks were used in addition to flint, which were often subjected to a similar preparation method as the flint raw material (e.g. Knutsson et al. 2016). This phenomenon is particularly noticeable in regions where flint is not found, or where it occurs in low numbers. Flint artefacts account for $51 \%$ of all rock finds at the Stone Age sites of Aukštumala, while finds made of other rocks (including flakes, blades and tools) account for $49 \%$. This is a significant figure, showing society's priority for individual groups of raw materials and substitutes for flint. Therefore, the technology of metamorphic rocks at Aukštumala is also discussed separately. No non-flint finds were reported during the 2004 excavations; therefore, only 2018 and 2019 data is included in this case. The archaeological material from the Aukštumala sites is stored in the Hugo Scheu Museum in Šilutè.

\section{Results}

\section{Dating}

A stratigraphy typical of sandy-type open-air Stone Age settlements was found at Aukštumala. Due to the natural environmental conditions, the sandy surface of the hill was covered in many places with thin layers of different types of peat, followed by the exposure of yellowish sand, the main cultural layer of the settlements with archaeological finds. Fine whitish fluvio-glacial sand lay under the yellowish sand. The peat on the sandy hill was formed by the annual growth of the upland bog. Such layers, but with much thicker layers of peat, were described in the hill at C.A. Weber's test pit No 8 section in the southern part of the sandy hill (Weber 1902). Unfortunately, however, the 2018 and 2019 excavations in all three sites revealed ploughing marks, which apparently appeared after a search for suitable areas for peat extraction in the 20th century. As has already been mentioned, this led to the excavation of the sandy hill itself, as well as damage to the archaeological layers of the Stone Age sites. During the archaeological research, in order to date the archaeological material, it was decided to take samples of organic finds (charcoal and charred hazelnut shells) found in the sandy layers for AMS ${ }^{14} \mathrm{C}$ dating. Three samples from site 1 were dated, and one sample from site 3. Unfortunately, all the dates go far beyond the existence of Final Palaeolithic Swiderian culture technology, and reach the 3rd millennium cal BC, and the 3 rd to 4 th and 8 th to 10 th centuries cal AD (Table 1 ). We believe these samples have nothing to do with prehistoric human activity in the sandy hill, because traces of the material culture of dated periods at all three Aukštumala sites were not found; the same could be said regarding the older excavations (Dakanis 2006; Rimkus and Girininkas 2019; 2020). Charcoal and burnt hazelnut shells may have been deposited in the layers naturally, during natural fires in the past and post-depositional factors.

Table 1. Dated organic samples from Aukštumala Stone Age sites 1 and 3. The ${ }^{14} \mathrm{C}$ dates were calibrated by OxCal v4.4 (Bronk Ramsey 2017) and the IntCal20 atmospheric curve (Reimer et al. 2020).

\begin{tabular}{|l|l|l|l|l|l|}
\hline Site & Dated material & Lab. No & ${ }^{14}$ C BP & cal BP (95.4\%) & cal BC/AD (95.4\%) \\
\hline Site 1 & Hazelnut shell & KIA-53320 & $4144 \pm 24$ & $4823-4575$ & $2874-2626$ BC \\
\hline Site 1 & Hazelnut shell & KIA-53323 & $4036 \pm 26$ & $4574-4421$ & $2625-2472$ BC \\
\hline Site 1 & Charcoal & KIA-53321 & $1744 \pm 21$ & $1706-1571$ & $245-380$ AD \\
\hline Site 3 & Charcoal & KIA-53322 & $1178 \pm 22$ & $1179-1001$ & $772-949$ AD \\
\hline
\end{tabular}




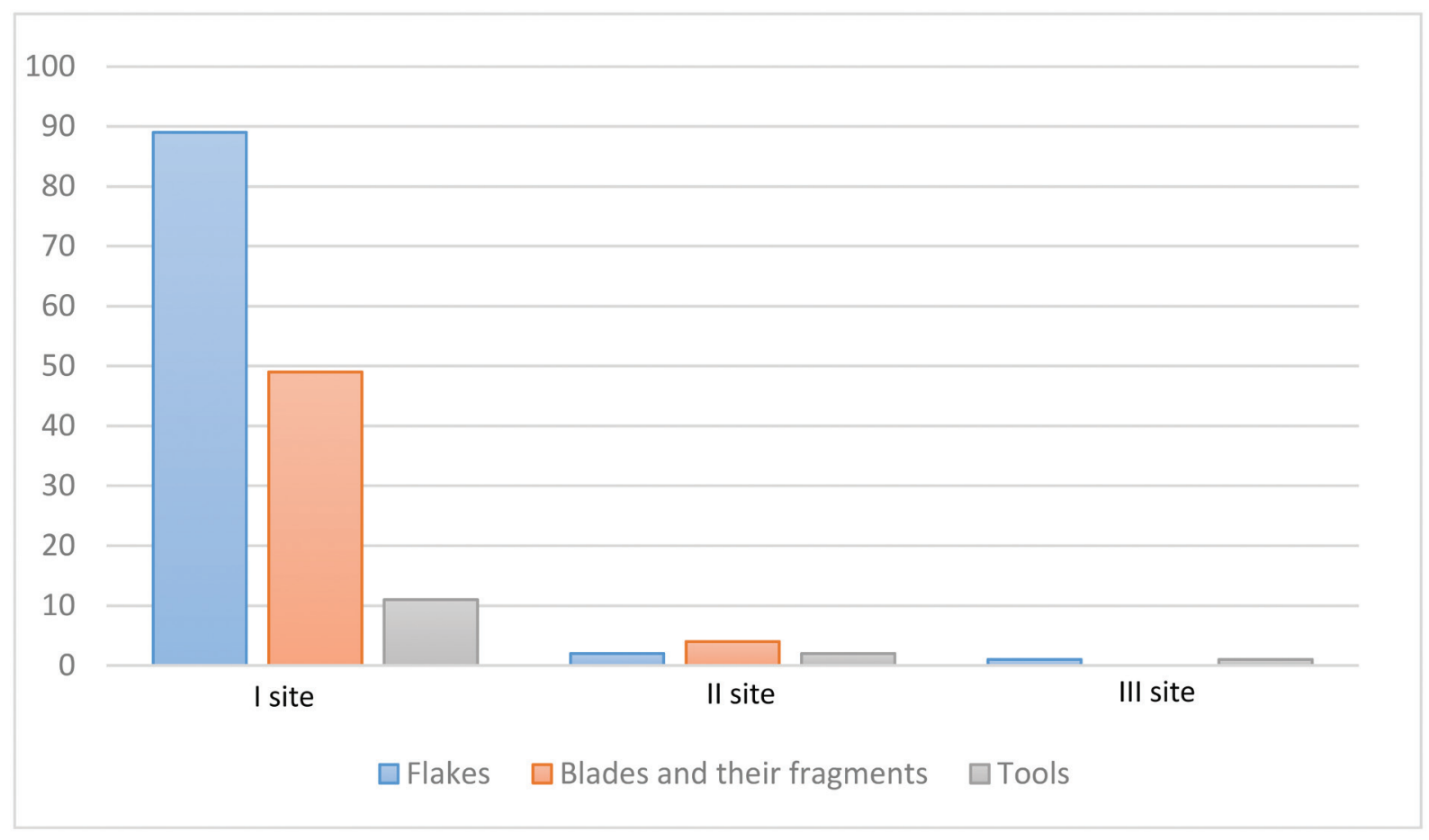

Figure 3. The total number of flint finds at Aukštumala sites 1, 2 and 3, found during the 2004 and 2018-2019 fieldwork (compiled by T. Rimkus).

\section{Flint technology}

Most of the lithic finds at Aukštumala sites 1, 2 and 3 are heavily affected by patination and heat. However, the lithics were probably affected by natural fires in former wetlands and peat extraction fields, and not by intentional heat treatment. Light grey cretaceous flint was used at the sites, some with surviving cortex, of which natural outcrops are found in southern Lithuania; however, occasional concentrations are also found in west Lithuania, including the upper reaches of the Nemunas (Baltrūnas et al. 2004; 2007).

Most of the flint finds were discovered at site 1, whereas sites 2 and 3 contained much fewer (Fig. 3). Flakes constituted most of the entire inventory, indicating local tool production. This difference between amounts of flint finds at separate sites can be explained by the difference in excavated territory (see above), and by the density of the finds in a single excavation trench, as the activity at site 1 was probably more intense.

Only 14 typologically distinct finds can be attributed to the tool category (Fig. 4). The most important finds, helping us to determine a preliminary chronology of the sites, are arrowheads, burins, and one opposite platform core. Points were located only at sites 1 and 3. Only two arrowheads are almost fully preserved, whereas the rest are only fragments of proximal parts. However, the flat retouch on the ventral surface of the fragments enables us to state that all the points should be attributed to Final Palaeolithic
Swiderian technology. The first point was manufactured from a small blade, and has a side retouch on the lower part on the ventral surface (Fig. 5.1). At first, it does not seem like a classic Swiderian point; however, if this find is compared with the next point from site 1 (Fig. 5.3), we might notice similarities in the side retouch on the lower part on the ventral surface. All the other points represent classic Swiderian willow leaf-shape point hunting implement technology (Fig. 5.2, 4-5).

The domestic tools consisted of one backed piece, a perforator, scrapers, burins, and a core axe (Fig. 6). Typologically, the burins represent classic Final Palaeolithic technology, with examples of an angle and dihedral burins. They are made from massive blades and flakes. Similar examples of burins are known from other Swiderian sites in Lithuania and Latvia (e.g. Šatavičius 2005; Zagorska 2012).

The core technology at the sites is represented by only one opposite platform core, which is entirely exhausted (Fig. 7.10). However, the blades offer much more information about producing blanks (Fig. 7) (Table 2). Most of the blades are large and fragmented, and their size attributions vary. The largest blades have a length of up to 71 millimetres, whereas the width and thickness are between ten and 20 millimetres, and three and seven millimetres, respectively (Fig. 8). The remains of the core platform and expressed bulb indicate that the blades were probably produced by the direct percussion technique, with a hard or soft hammer, but narrow blades could also indicate the 


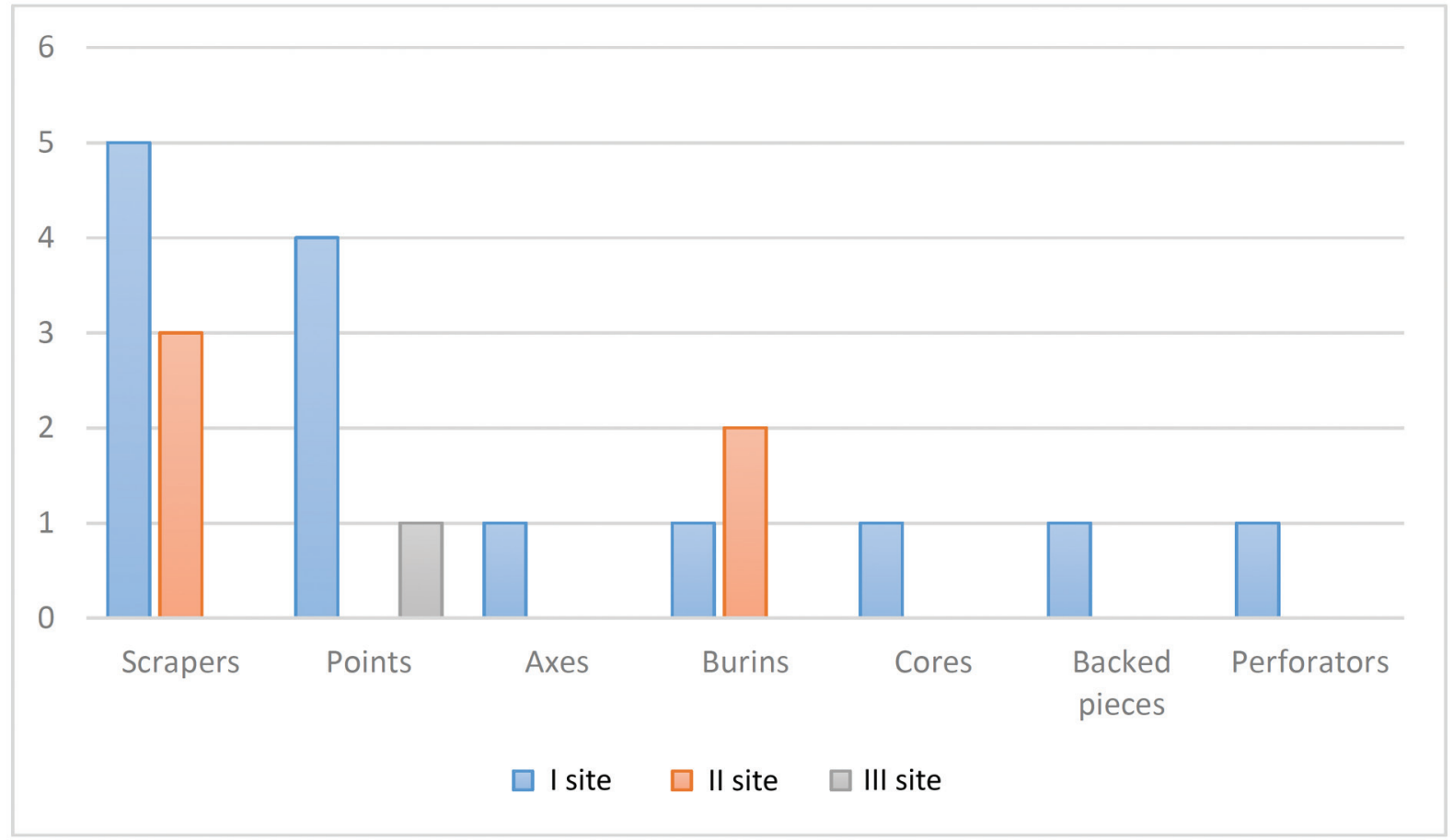

Figure 4. The total number of tools found at Aukštumala sites 1, 2 and 3 during the 2004 and 2018-2019 fieldwork (compiled by T. Rimkus).

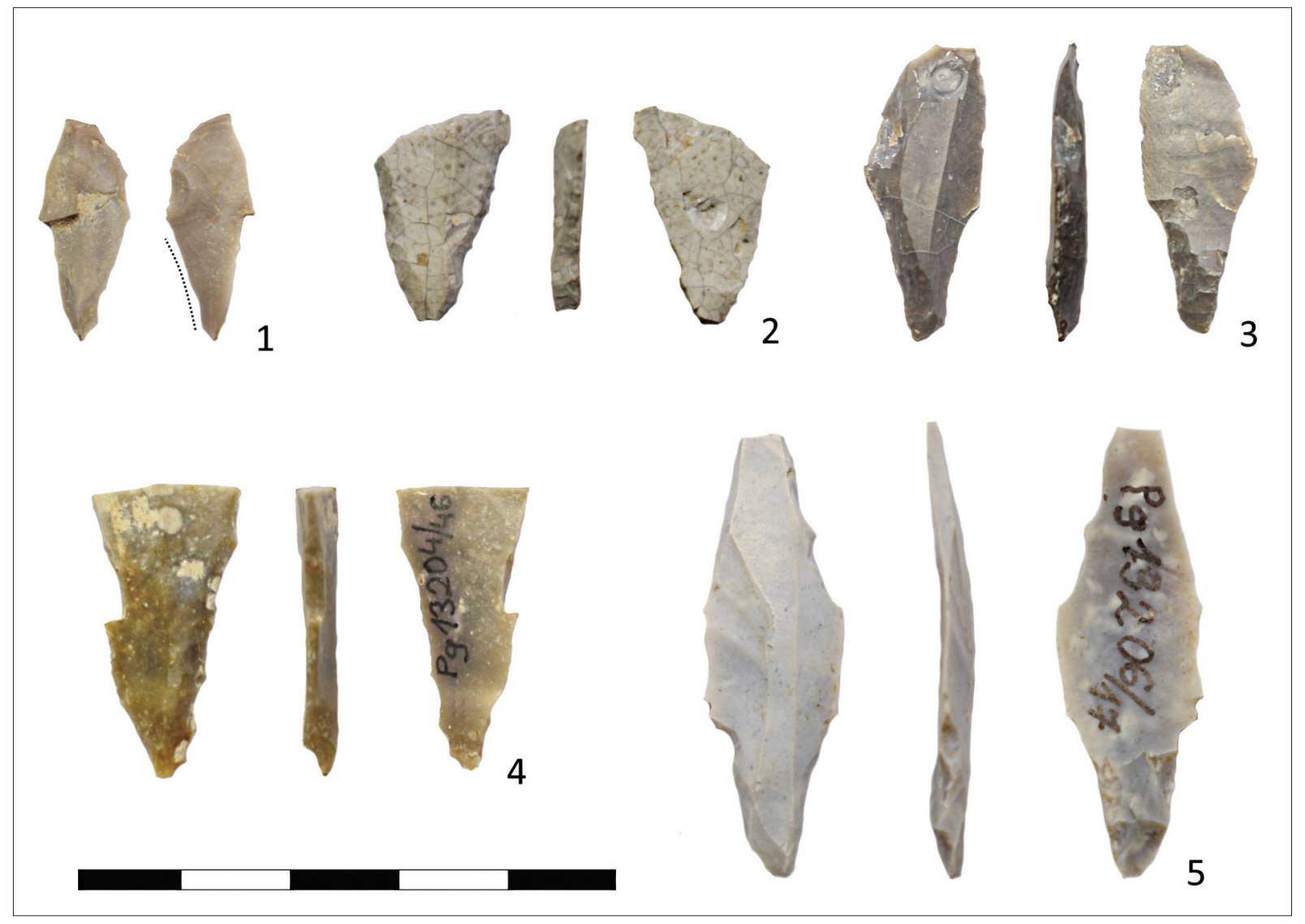

Figure 5. Arrowheads found at the Aukštumala sites during the 2004 and 2018-2019 fieldwork: 1-3. site 1; 4. site 3 (photograph by T. Rimkus). 


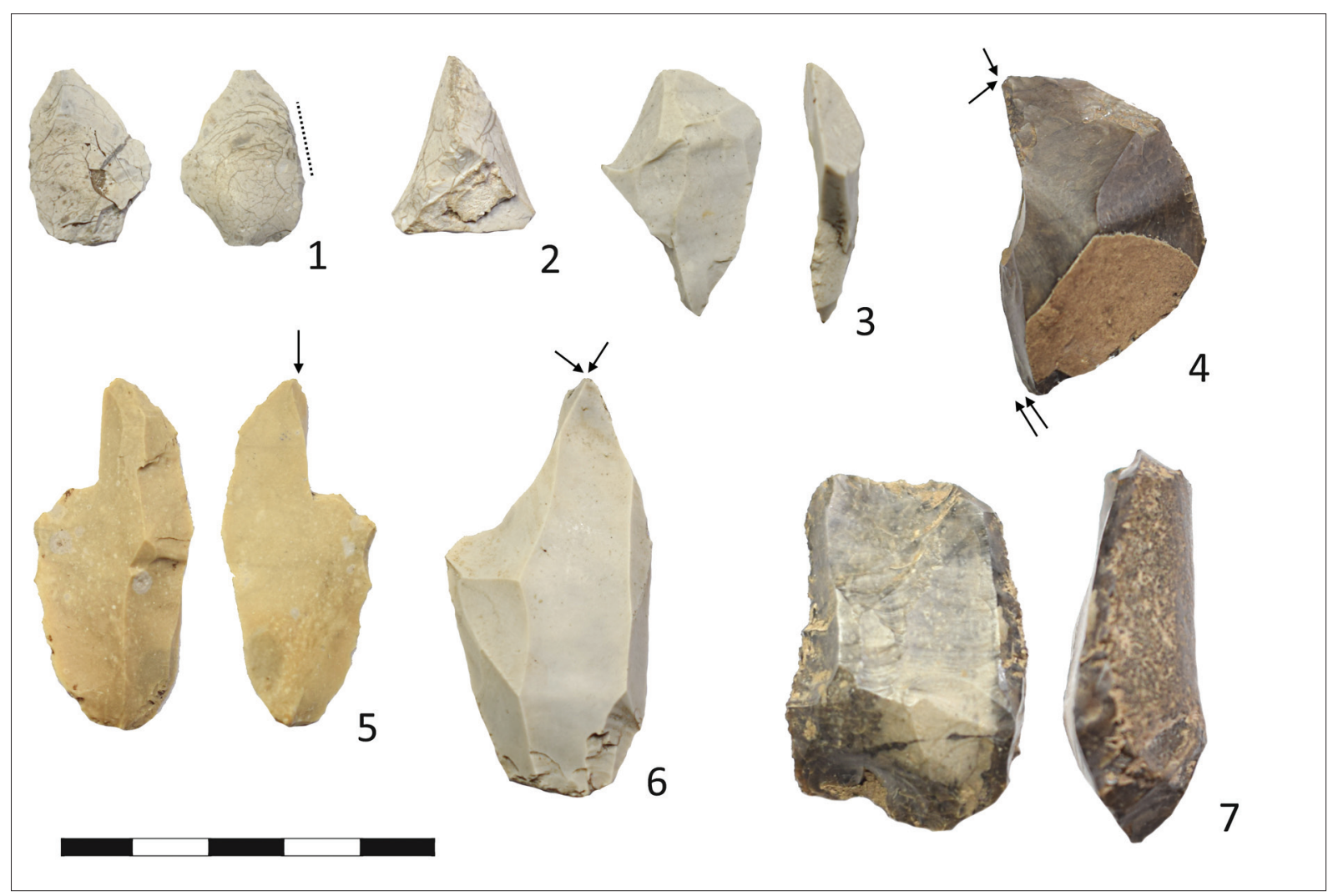

Figure 6. Flint tools found at the Aukštumala sites during the 2004 and 2018-2019 fieldwork: 1. backed piece (sites 1); 2. perforator (site 1); 3. scraper (site 2); 4-6. burins (sites 1 and 2); 7. core axe (site 1) (photograph by T. Rimkus).

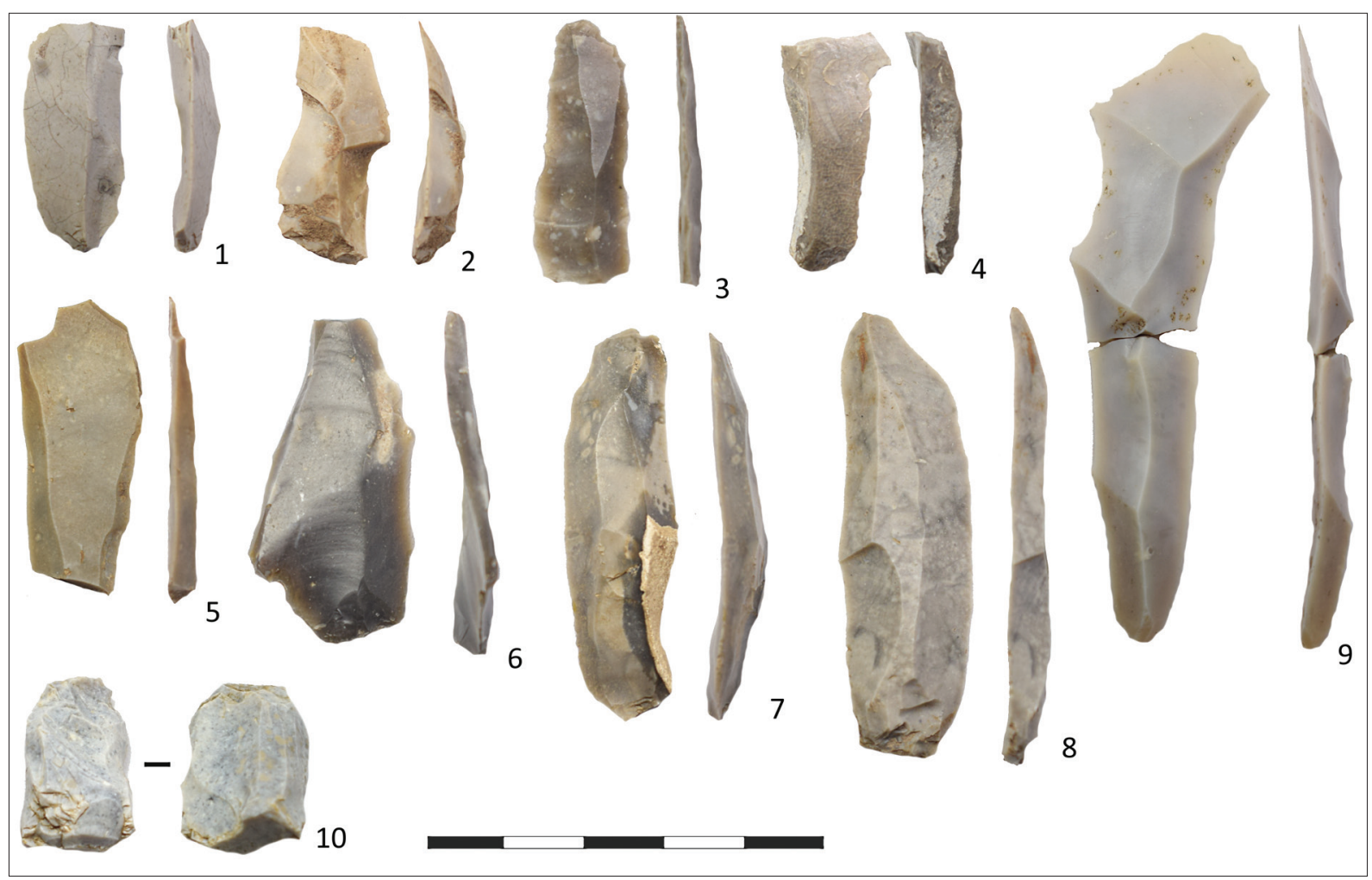

Figure 7. Flint blades (1-9) and the opposite platform core (10) found at Aukštumala sites 1 and 2 during the 2004 and 2018-2019 fieldwork (photograph by T. Rimkus). 


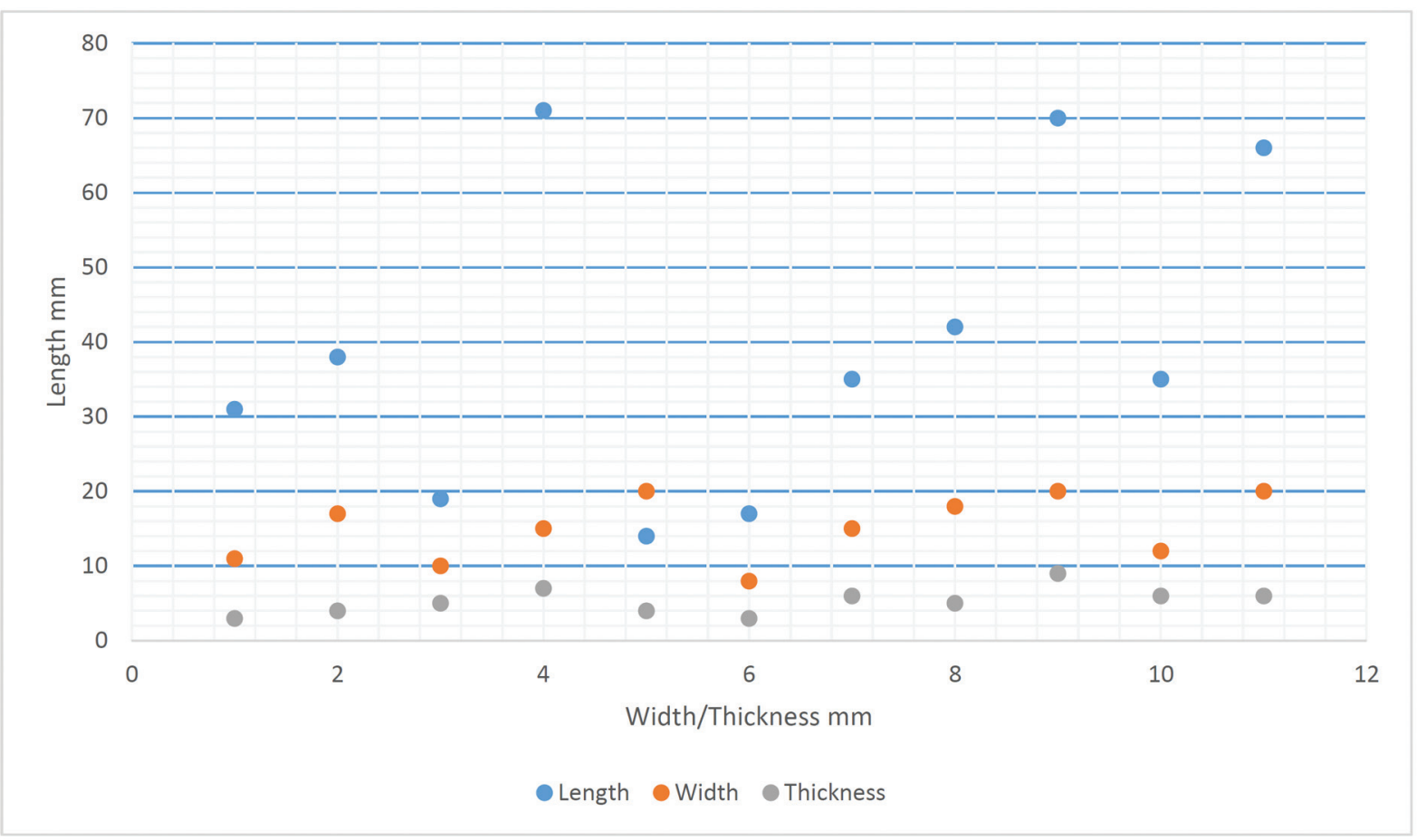

Figure 8. The size attributes of flint blades found at Aukštumala sites 1 and 2 (compiled by T. Rimkus).

Table 2. Flint blade attributes at Aukštumala sites 1 and 2.

\begin{tabular}{|l|l|l|l|l|l|l|l|l|}
\hline Status & Bulb & $\begin{array}{l}\text { Core plat- } \\
\text { form }\end{array}$ & Colour & $\begin{array}{l}\text { Length } \\
\text { mm }\end{array}$ & $\begin{array}{l}\text { Width } \\
\mathbf{m m}\end{array}$ & $\begin{array}{l}\text { Thickness } \\
\mathbf{m m}\end{array}$ & Cortex & $\begin{array}{l}\text { Other fea- } \\
\text { tures }\end{array}$ \\
\hline $\begin{array}{l}\text { No proximal } \\
\text { part }\end{array}$ & No & No & Dark grey & 31 & 11 & 3 & No & $\begin{array}{l}\text { Triangular } \\
\text { cross-section }\end{array}$ \\
\hline $\begin{array}{l}\text { Lack small frag- } \\
\text { ment of distal } \\
\text { part }\end{array}$ & Yes & Yes & Dark grey & 38 & 17 & 4 & No & $\begin{array}{l}\text { Trapezoid } \\
\text { cross-section }\end{array}$ \\
\hline No distal part & $\begin{array}{l}\text { Barely } \\
\text { visible }\end{array}$ & No & $\begin{array}{l}\text { Light grey; } \\
\text { burnt }\end{array}$ & 19 & 10 & 5 & No & $\begin{array}{l}\text { Triangular } \\
\text { cross-section; } \\
\text { curved }\end{array}$ \\
\hline Fully preserved & $\begin{array}{l}\text { Barely } \\
\text { visible }\end{array}$ & No & Light grey & 71 & 15 & 7 & No & $\begin{array}{l}\text { Triangular } \\
\text { cross-section; } \\
\text { curved }\end{array}$ \\
\hline No distal part & Yes & Yes & Dark grey & 14 & 20 & 4 & No & $\begin{array}{l}\text { Triangular } \\
\text { cross-section }\end{array}$ \\
\hline No distal part & No & No & $\begin{array}{l}\text { Dark grey; } \\
\text { burnt }\end{array}$ & 17 & 8 & 3 & No & $\begin{array}{l}\text { Triangular } \\
\text { cross-section }\end{array}$ \\
\hline Fully preserved & No & No & $\begin{array}{l}\text { Light grey; } \\
\text { burnt }\end{array}$ & 35 & 15 & 6 & $\begin{array}{l}\text { Curved in the } \\
\text { distal part }\end{array}$ \\
\hline $\begin{array}{l}\text { No proximal } \\
\text { part }\end{array}$ & - & - & Light grey & 42 & 18 & 5 & No & $\begin{array}{l}\text { Trapezoid } \\
\text { cross-section; } \\
\text { straight }\end{array}$ \\
\hline Fully preserved & Yes & Yes & Dark grey & 70 & 20 & 9 & White & $\begin{array}{l}\text { Curved in the } \\
\text { proximal part }\end{array}$ \\
\hline $\begin{array}{l}\text { Only proximal } \\
\text { part }\end{array}$ & $\begin{array}{l}\text { Barely } \\
\text { visible }\end{array}$ & No & $\begin{array}{l}\text { Dark grey; } \\
\text { burnt }\end{array}$ & 35 & 12 & 6 & White & $\begin{array}{l}\text { Curved in the } \\
\text { distal part }\end{array}$ \\
\hline Fully preserved & No & Yes & Dark grey & 66 & 20 & 6 & $\begin{array}{l}\text { Slightly } \\
\text { curved in the } \\
\text { distal part }\end{array}$ \\
\hline
\end{tabular}




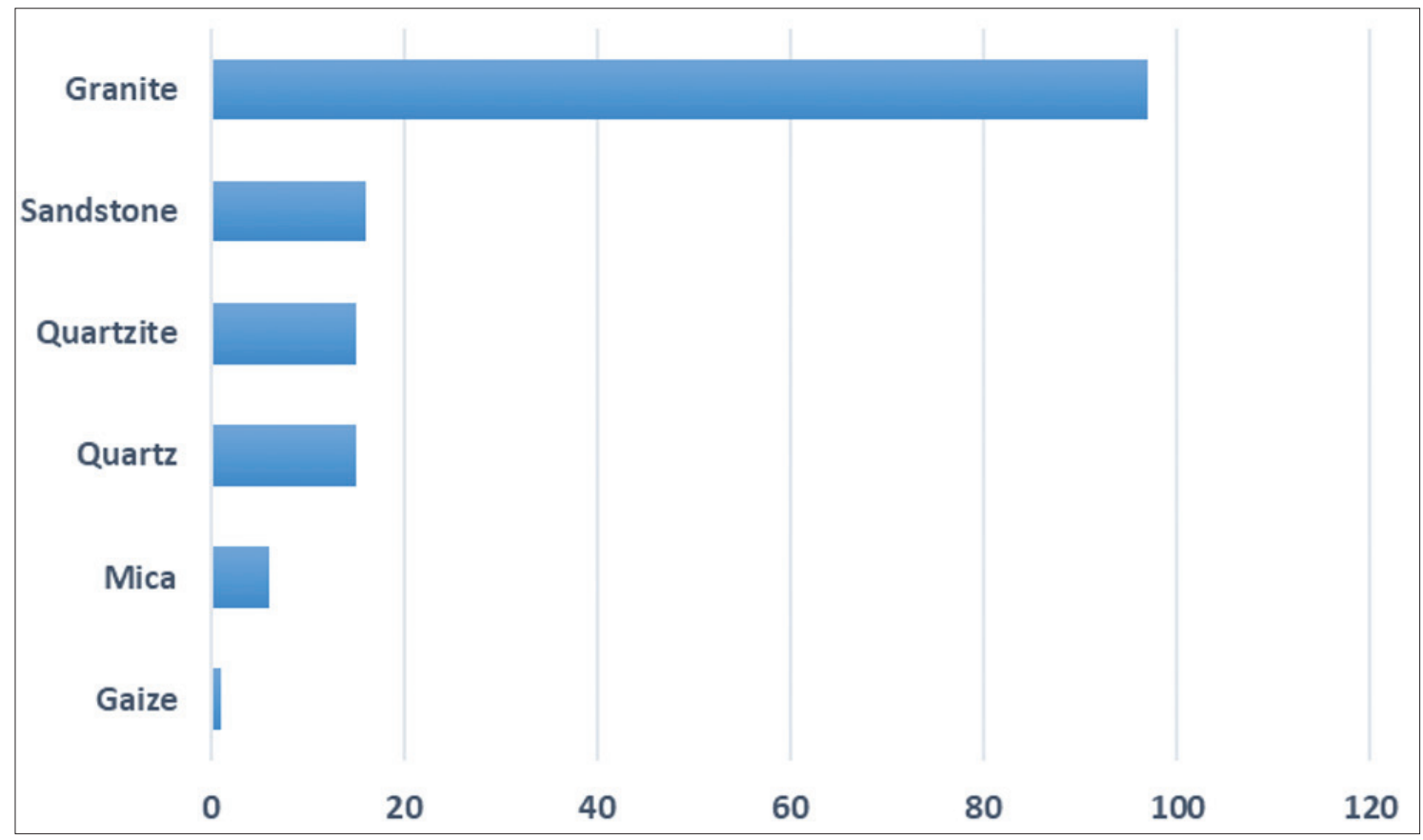

Figure 9. The number of metamorphic rock finds found at Aukštumala sites 1-3 during the 2018-2019 fieldwork (compiled by T. Rimkus).

indirect percussion technique. The negatives on the blades have features of a single or opposite platform cores, which would indicate both core types used at the sites. Figure 7 shows only almost fully preserved blades; however, the rest of the blades are heavily fragmented and burnt. Some of them are much smaller in size, and have more regularity regarding the negatives. They are very similar to some of the regular blades found at Pulli, or post-Swiderian lithic complexes (Ostrauskas 2000). However, no typical Pulli lithic implements were found at Aukštumala, and the technological relationship between the two technologies can only be deduced by several blade fragments, which suggests that more data is required.

\section{Metamorphic rocks}

Non-flint raw material and implements are often found in Stone Age sites. Flint technology is described as the main technology used by prehistoric societies; however, metamorphic rocks are often underrated and sometimes poorly represented in Stone Age studies. One of the largest Final Palaeolithic sites in Lithuania that contain non-flint tools and waste is Pasieniai 1, in east Lithuania (Šatavičius 2012). Its lower C layer represents Swiderian technology, and non-flint finds are associated with it. At the Aukštumala Stone Age sites, 150 non-flint finds, including knapping waste, blades and tools, were identified during the 2018 and 2019 fieldwork. The raw materials vary; however, a different kind of granite dominates among all the raw materials. Sandstone, quartzite, quartz, mica and gaize are other raw materials that were also used for tool production, but in much smaller numbers (Fig. 9).

The identified toolkit made of metamorphic rocks is very small, and only a few characteristic cases were distinguished. One of the most interesting tools was identified as a point made from a granite flake (Fig. 10.1). Its tip was shaped by retouch, which is located on both sides of the point in its distal part. No retouch was found on the ventral part. The technology of this point differs from classic Swiderian arrowheads made from flint; however, this find is missing its proximal part. On the other hand, there is still little data on Swiderian non-flint hunting implement technology in the east Baltic. The next find was identified as the middle part of a granite blade (Fig. 10.2). Both sides have fractures that could have formed during use; therefore, this find most likely represents a cutting tool. However, use-wear examinations should be conducted in order to support this.

The following non-flint finds represent knapping techniques. This category includes granite hammerstone (Fig. 10.3) and single-platform granite cores (Fig. 10.4, 5). The hammerstone is round, and both ends are heavy worn. Negatives from blades and flakes are left on the surface of the cores, whereas their platforms are wide and faceted.

Most of the non-flint finds (79 in total) were found in the area of site 3, where cores, a hammerstone, an arrowhead and a fragment of a blade were found, and are described in this chapter. Only two flint finds were found at this site: an arrowhead typical of Swiderian willow leaf-shape point 


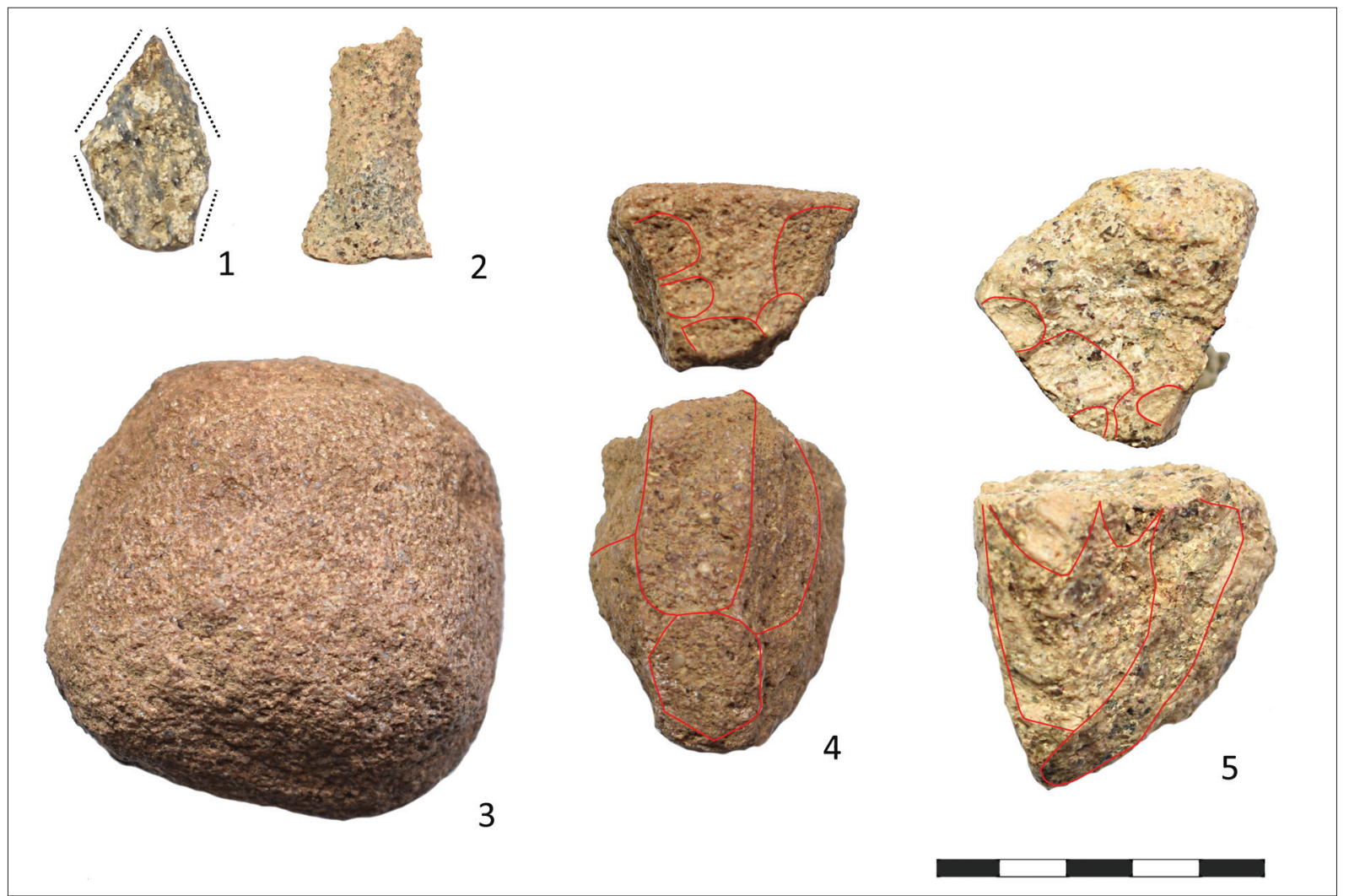

Figure 10. Non-flint tools found at Aukštumala site 3 during the 2018-2019 fieldwork: 1. a piece of an arrowhead; 2. a blade fragment (probably a cutting tool); 3. a hammerstone; $4-5$. single platform cores (photograph by T. Rimkus).

technology (Fig. 4.5), and a burin spall. Sites 1 and 2 are dominated by flint finds, while fewer finds from other rocks have been found. Therefore, we would argue that site 3 may have been a site for processing various locally found metamorphic rocks. Among the other finds of non-flint rocks, there was much knapping debris and a few larger stones with signs of knapping and grinding, which does not allow us to suggest clearly their function or how they were used.

\section{Discussion}

Until now, only one area is known in the current Lithuanian coastal zone with finds from the Final Palaeolithic: the eastern part of Aukštumala bog. It contains three separate sites, excavated in 2004, and in 2018 and 2019. All the other Stone Age finds on the Lithuanian coast are associated with the end of the Mesolithic or the Neolithic (Piličiauskas 2016; Rimkus 2019). The bone implements found at Kalniškiai (formerly Bachmann manor) close to Klaipèda (Groß 1939, p. 111; Rimantienè 1971, p. 35) cannot be reliably connected with Final Palaeolithic chronology, as dating studies have not so far been performed, and their typological features would be more reminiscent of Mesolithic artefacts (e.g. Zhilin et al. 2014; Zhilin 2020, Fig. 7). In 2021, in the village of Püzraviečiai, close to the left bank of the River Ašva, about 20 kilometres northeast of the Aukštumala sites, a single Swiderian-type arrowhead was found. It is made of a slightly curved 86-millimetre-long, 21-millimetre-wide, and nine-millimetre-thick blade, which is covered with a light brownish patina, and is formed from a single platform core (Fig. 11). The arrowhead has a very characteristic tang with a flat retouch on the ventral surface. Therefore, at present, this and the finds of Swiderian culture found at the Aukštumala sites are the only firm evidence of Final Palaeolithic societies on the current Lithuanian coast.

Most of the Swiderian culture arrowheads found at Aukštumala are fragmented; but from the surviving tang elements, it can be assumed that they should be attributed to the category of willow leaf-shape points. This is also confirmed by two fully preserved points (Figs. 4.3 and 5), which do not have distinctly shaped pointed tangs. Comparing the technology of these arrowheads with the find from the village of Pūzraviečiai, there are significant differences in the characterisation of the tangs and the size of the blanks. Therefore, according to the classic periodisation of Swiderian culture (Schild 1975), these points belong to separate groups: with a distinctly shaped pointed tang, dated to the Younger Dryas (the case of Pūzraviečiai); and with willow leaf-shape points, dating from the beginning of the Preboreal (the case of Aukštumala). However, 


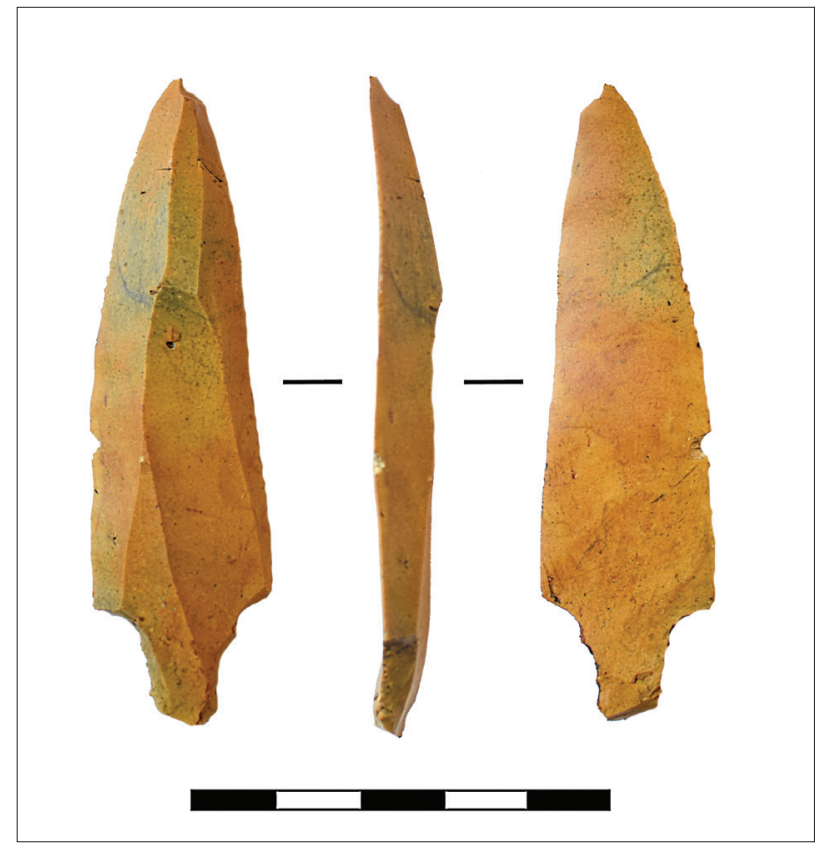

Figure 11. The Swiderian arrowhead found in the village of Pūzraviečiai (photograph by T. Rimkus)

there is no clear chronological clarity in this division. There is still a lack of data on the chronological differences between these two individual technological stages, and the time when these hunting implement technologies are interchangeable, or possibly used in parallel. Both types of arrowheads are often found together in Swiderian culture sites in Lithuania; therefore, it cannot be ruled out that both types of hunting implement could have been used simultaneously.

It is difficult to estimate in what form the flint raw material was brought to the Aukštumala sites. No nodules were obtained, whereas only one exhausted opposite platform core was found at site 1 . The large number of flakes at site 1 would perhaps suggest that flint was worked on the site, and it is possible that cores were completely used or transformed into tools, like, for example, the core axe found at site 1 . However, this may apply to site 1 , as the other sites do not have a large number of flakes, and mostly completed tools or blades were found there. Therefore, this may suggest that the flint was worked elsewhere, and only later brought to site 2, for example. But, in order to improve this hypothesis, it would be necessary to study a larger area at site 2 .

So far, there is little radiocarbon data on the dating of Swiderian culture in the east Baltic region. The present data from the lower $\mathrm{C}$ layer of the Kabeliai 2 site in southern Lithuania indicates that Swiderian tanged and willow leaf-shape points, and opposite platform cores, probably belong to the end of the Younger Dryas and the first half of the Preboreal (Ostrauskas 2002, Table 14). Apart from the Kabeliai 2 site in southern Lithuania, there are few other radiocarbon dates that would resemble Swiderian chronology. However, the recent dating of stray osseous finds from Lithuania and Latvia puts them in the Younger Dryas and the Early Preboreal (Meadows et al. 2014; Rimkus et al. 2019), that is, the chronology of the Swiderians. However, the finds lack context data to relate them firmly to Swiderian bone technology. More data is available from Swiderian sites in Poland, where radiocarbon dating has been applied. The dated animal bones, wood charcoal and pollen from the major sites also indicate the continuity of the techno-complex from the Younger Dryas to the Preboreal (Płonka et al. 2020; Schild 2014, pp. 48-55; Winkler 2019, Table 1). No reliable radiocarbon data has been obtained from the Aukštumala sites (Table 1). Therefore, the settlements can only be dated on a preliminary basis, based on the technological features of the finds and geological data. The Aukštumala upland bog is located in the Nemunas delta region, where geological surveys have been carried out to determine the change in the water level of the Baltic in the Lithuanian coastal region. According to the core and sediment studies published by Damušyte (2011, p. 53), the Aukštumala upland bog was not formed during the Younger Dryas, and most likely the favorable conditions for human habitation at the fluvioglacial hill in the eastern part of the Aukštumala upland bog became available in the Preboreal with the onset of Yoldia Sea water level regression. During the Preboreal, the water level declined, and the area in question must have been on dry land, as the water level fell sharply during the Yoldia Sea stage, and the shoreline was west of the current east Baltic region at -55 to $-53.4 \mathrm{~m}$ a.s.l. (Gelumbauskaite 2009; Rosentau et al. 2017; Žulkus and Girininkas 2020). Based on the Swiderian culture technology found at Aukštumala, and the existing chronology in adjacent countries (Schild et al., 1999; p. 15; Winkler 2019, Table 1; Płonka et al. 2020, Table 1), we can assume that the sandy hill in the eastern part of Aukštumala could have been inhabited during the Preboreal. It is probable that no larger water basin had formed in the eastern part of Aukštumala at that time ${ }^{2}$, and the hill itself could have existed next to a smaller body of water.

Peat studies from the western part of the Aukštumala wetland reveal that different peat types (wood, wood-sedge, reed) formed here during the emergence of the lowland bog. It was only much later that layers characteristic of upland bogs were formed by Eriophorum, Pinus-Eriophorum, Scheuchzeria palustris-Sphagnum peat, and only in the lat-

2 This is evidenced by sediment studies from cores dated to the mid-Holocene, and published by Damušyte (2011, p. 66), as well as by new sediment analyses from wetland areas adjacent to the archaeological sites conducted during the 2018 and 2019 fieldwork, of which the results will be published separately. 
est period did Sphagnum peat cover the current eastern upland wetland part of the Aukštumala bog, including the sandy hill (Weber 1902; Kunskas 2005).

There is currently little data on the function of individual sites at Aukštumala. It also lacks organic finds and features, but such objects are often poorly preserved in sandy Stone Age sites, especially in Final Palaeolithic contexts. However, based on the abundance of non-flint rock finds at site 3 , including hammerstone, cores, and large amounts of knapping debris, we would suggest that this area may have existed as a metamorphic rock-processing site. Granite, quartz, sandstone, gaize and other rocks, which were suitable for replacing flint raw material, are found locally in the Nemunas delta region and its surroundings. We assume that metamorphic rocks should not always be treated as just a substitute for flint raw material. Such materials were important in the production of other tools, such as hammerstones, net weights, or grinding plates, which prehistoric societies did not produce from flint. The chronological relationship between all three sites also remains unclear. Although willow leaf-shape points and blade technology, large dihedral burins and cores were found in all the sites, their relationship cannot be explained at present due to the lack of reliable data.

Data about subsistence strategies at Aukštumala is also scarce. There is currently only data about reindeer (Rangifer tarandus) as the main hunted animal species during the Final Palaeolithic in Lithuania. There is evidence of reindeer skeletal remains in the coastal parts of Lithuania and the Kaliningrad oblast as well, published in the 20th century by Groß (1940), which could belong to the very end of the Late Glacial. This data was later referred to several times in studies on the Lithuanian prehistoric subsistence economy (Daugnora and Girininkas 2005, Fig. 2; Girininkas 2009, Fig. 14; Girininkas and Daugnora 2013, Fig. 1; 2015, Fig. 20). However, the skeletal remains found on the Lithuanian coast are not radiocarbon dated, and there is currently no possibility to compare or associate their age with the relative Swiderian chronology at Aukštumala.

Following the discussion of the radiocarbon data obtained, the table shows that two radiocarbon dates are available for the cal AD period (Table 1). Based on the periodisation of the Iron Age used in Lithuanian archaeology (e.g. Bliujienè 2013, Table 7; Žulkus and Jarockis 2013, p. 10), the dates would fall into the Roman Iron Age (KIA53321), and the Migration period to the Viking Age (KIA53322). However, these dates do not in any way confirm the human activity in the eastern part of the Aukštumala bog during later periods, which could be related to the hillfort mentioned in literature (Bezzenberger 1892; Dakanis 2006; Baubonis et al. 2017, pp. 16-17). We will repeat that no archaeological finds have been discovered from the latter periods; therefore, it should be assumed that the dated charcoal found in the sandy layers occurred naturally, possibly from natural forest fires or other postdepositional factors.

\section{Conclusions}

In 2004, Stone Age sites discovered in the eastern part of Aukštumala bog provided the first data on the Final Palaeolithic in the Lithuanian coastal area. In 2018 and 2019, the re-investigation of the Aukštumala sites supplemented this data, and provided new technological and chronological interpretations. Three Final Palaeolithic Swiderian culture sites at Aukštumala with flint and metamorphic rock finds are currently known in the Lithuanian coastal region. One single tanged point of Swiderian culture was also found at the village of Pūzraviečiai, about 20 kilometres northeast of the Aukštumala Stone Age sites. The technique of processing lithic material in the coastal region differed little from finds of Swiderian culture found in the mainland. This could also be due to the lack of local raw materials, as the flint and technological knowledge could have travelled to the western peripheries of Lithuania. The differences are mostly observed only in the amount of processing of other metamorphic rocks, choosing them as a substitute for local flint raw material. The finds found at Aukštumala are assigned to the willow leaf-shape point technological stage, which is dated to the Preboreal period. At present, there is little data on the economies of prehistoric communities in the Aukštumala sites, and the chronological connection between the three separate sites remains unclear. Nevertheless, the research at Aukštumala and its archaeological material have provided the first technological data on Final Palaeolithic communities in the current Lithuanian coastal area, and their possible connection with the environment.

\section{Acknowledgements}

This paper was prepared as part of the research project 'Man and the Baltic Sea in the Meso-Neolithic: Relict Coasts and Settlements below and above Present Sea Level. ReCoasts\&People. The research was funded by the European Social Fund according to the activity 'Improvement of Researchers' Qualifications by Implementing World-Class R\&D Projects' and a grant (No 09.3.3-LMTK-712-01-0171) from the Research Council of Lithuania. We are thankful to Laisvūnas Kavaliauskas and Edvardas Bočkus for providing information on the tanged point find from Pūzraviečiai. Finally, we would like to thank the two anonymous reviewers for their valuable comments and suggestions on a previous version of this paper. 


\section{Abbreviations}

Archaeol. Baltica - Archaeologia Baltica

ATL - Archeologiniai tyrinèjimai Lietuvoje ... . metais. Vilnius (since 1967)

Lietuvos Arch. - Lietuvos archeologija. Vilnius (since 1979)

\section{References}

Baltrūnas, V., Karmaza, B., Kulbickas, D., Pukelyte, V., 2004. Mineralinès žaliavos, jų paplitimas Virvytès, Minijos ir Varduvos aukštupiuose. Acta Academiae Artium Vilnensis, 34, 33-44.

Baltrūnas, V., Karmaza, B., Kulbickas, D., Ostrauskas, T., 2007. Egzotine titnago bei titnago pakaitalų žaliava Lietuvos akmens ir žalvario amžiaus gyvenvietėse. Lietuvos Arch., 31, 109-122.

Baubonis, Z., Stončius, D., Šatavičius, E., Zabiela, G., 2017. Lietuvos piliakalniai. Atlasas, Vol. 4. Vilnius: Lietuvos archeologijos draugija.

Berg-Hansen, I.M., Damlien, H., Kalnin̦š, M., Zagorska, I., Schülke, A., Bērziņš, V., 2019a. Long-term variation in lithic technological traditions and social interaction: the Stone Age of the eastern Baltic (Latvia), 10500-2900 cal BC. Fennoscandia Archaeologica, 36, 6-32.

Berg-Hansen, I.M., Damlien, H., Zagorska, I., 2019b. The northern fringe of the Swiderian technological tradition: Salaspils Laukskola revisited. Archaeol. Baltica, 26, 12-31. https://doi. org/10.15181/ab.v26i0.2020

Bezzenberger, A., 1892. Der Schlossberg im Augstumaller moor. Sitzungsberichte der altertumsgesellschaft Prussia, 17, 40-43.

Bliujienè, A., 2013. Romèniškasis ir tautu kraustymosi laikotarpiai. In: Lietuvos Archeologija, t. III. Klaipedda: Klaipèda Universiteto leidykla.

Bronk Ramsey, C., 2017. Methods for summarizing radiocarbon datasets. Radiocarbon, 59 (6), 1809-1833. https://doi. org/10.1017/RDC.2017.108

Crome, H., 1938. Verzeichnis der Wehranlagen Ostpreussens. Prussia. Zeitschrift für Heimatkunde. Königsberg.

Dakanis, B., 2006. Lapalių (Aukštumalos) senovès gyvenvietès. ATL 2004 metais. Vilnius: Lietuvos archaeologijos draugija, pp. 11-13.

Damušyte, A., 2011. Post-glacial geological history of the Lithuanian coastal area. Summary of doctoral dissertation. Vilnius University.

Danusevičius, D., Buchovska, J., Žulkus, V., Daugnora, L., Girininkas, A., 2021. DNA markers reveal genetic associations among 11,000-years-old scots pine (Pinus sylvestris L.) found in the Baltic Sea with the present-day gene pools in Lithuania. Forests, 12 (3), 1-16. https://doi.org/10.3390/f12030317

Daugnora, L., Girininkas, A., 2005. Šiaurès elnių keliai ir jų paplitimas Lietuvoje vèlyvajame paleolite. Lietuvos Arch., 29, 119-132.

Gelumbauskaitè, L.Ž., 2009. Character of sea level changes in the subsiding south - eastern Baltic Sea during Late Quaternary. Baltica, 22 (1), 23-36.

Girininkas, A., 2009. Akmens amžius. In: Lietuvos archeologija, t. I. Vilnius: Versus Aureus.

Girininkas, A., 2011. New data on Palanga Stone Age settlement. Archaeol. Baltica, 16, 48-57. http://dx.doi.org/10.15181/ ab.v16i0.33
Girininkas, A., Daugnora, L., 2013. Hunting in the territory of Lithuania from the Late Palaeolithic to the Middle Ages. In: O. Grimm, U. Schmölcke, eds. Hunting in northern Europe until 1500 AD. Old traditions and regional developments, continental sources and continental influences. Neumünster: Wachholtz, pp. 567-595.

Girininkas, A., Daugnora, L., 2015. Ükis ir visuomene Lietuvos priešistorèje, t. I. Klaipèda: Klaipèdos universiteto leidykla.

Grigaliūnas, M., 2013. The First Palaeolithic and Mesolithic Settlements in Aukštumala, Šilute District, the Nemunas River Delta. Archaeol. Baltica, 20, 174-189. http://dx.doi. org/10.15181/ab.v20i0.815

Groß, H., 1939. Die subfossilen renntierfunde Ostpreußens. Schriften der physikalisch-ökonomischen gesellschaft zu Königsberg, Band 1, 79-126.

Groß, H., 1940. Das renntier in der Ostpreußischen vorgeschichte. Altpreußen, 1, 1-4.

Grużdź, W., 2018. An examination of theories on lithic reduction methods in Swiderian technology. In: K. Knutsson, H. Knutsson, J. Apel, H. Glørstad, eds. Technology of early settlement in northern Europe. Transmission of knowledge and culture. The early settlement of northern Europe Vol. 2. Sheffield/Bristol: Equinox publishing, 47-61. http://dx.doi.org/10.1558/equinox.30725

Gudaitienè, G., 2020. Eiguliai, One of Rimutè Rimantienès First Excavations - a Revised Interpretation. Lietuvos Arch., 46, 33-63. https://doi.org/10.33918/25386514-046001

Hollack, E., 1908. Erlauterungen zur vorgeschichtlichte uebersichtskarte von Ostpreussen. Glogau-Berlin: Flemming.

Knutsson, K., Knutsson, H., Molin, F., Zetterlund, P., 2016. From flint to quartz: organization of lithic technology in relation to raw material availability during the pioneer process of Scandinavia. Quaternary International, 424, 32-57. https://doi. org/10.1016/j.quaint.2015.10.062

Kunskas, R., 2005. Ežerų ir pelkiu ekosistemu raida. Mažasis paleogeografijos ir paleosinekologijos atlasas. Vilnius: Ciklonas.

Meadows, J., Eriksen, B.V., Zagorska, I., Dreves, A., Simpson, J., 2014. Dating Late Palaeolithic harpoons from Lake Lubāns, Latvia. Radiocarbon, 56 (2), 581-589. https://doi. org/10.2458/56.16957

Ostrauskas, T., 2000. Mesolithic Kunda Culture. A Glimpse from Lithuania. Muinasaja Teadus, 8, 167-180.

Ostrauskas, T., 2002. Kabeliai 2 Stone Age Site. Archaeol. Baltica, 5, 51-82.

Piličiauskas, G., 2016. Lietuvos pajūris subneolite ir neolite. Žemès ūkio pradžia. Lietuvos Arch., 42, 25-103.

Piličiauskas, G., Luik, H., Piličiauskienė, G., 2015. Reconsidered Late Mesolithic and Early Neolithic of the Lithuanian Coast: the Smelte and Palanga Sites. Estonian Journal of archaeology, 19 (1), 3-28. doi: 10.3176/arch.2015.1.01

Płonka, T., Bobiak, D., Szuta, M., 2020. The dawn of the Mesolithic on the plains of Poland. Journal of World Prehistory, 33, 325-383. https://doi.org/10.1007/s10963-020-09146-0

Pyżewicz, K., Grużdź, W., Serwatka, K., Sobkowiak-Tabaka, I., Stefański, D., 2019. Swiderian lithic assemblages from Poland - some new observations and ideas. In: C. Montoya, J.-P. Fagnart, J.-L. Locht, eds. Préhistoire de l'Europe du Nord-Ouest. Mobilités, climats et identités culturelles. Volume 2: Paléolithique supérieur ancient, Paléolithique final - Mésolithique. XVIIIe congress préhistorique de France, Amiens, 30th mai - 4th juin 2016. Paris: Société Préhistorique Française, pp. 511-528. Reimer, P.J., Austin, W.E.N., Bard, E., Bayliss, A., Blackwell, P.G., Bronk Ramsey, C., Butzin, M., Cheng, H., Edwards, R.L., Friedrich, M., Grootes, P.M., Guilderson, T.P., Hajdas, I., Heaton, T.J., Hogg, A.G., Hughen, K.A., Kromer, B., Manning, S.W., 
Muscheler, R., Palmer, J.G., Pearson, Ch., van der Plicht, J., Reimer, R.W., Richards, D.A., Scott, E.M., Southon, J.R., Turney, C.S.M., Wacker, L., Adolphi, F., Büntgen, U., Capano, M., Fahrni, S.M., Fogtmann-Schulz, A., Friedrich, R., Köhler, P., Kudsk, S., Miyake, F., Olsen, J., Reinig, F., Sakamoto, M., Sookdeo, A., Talamo, S., 2020. The IntCal20 northern hemisphere radiocarbon age calibration curve $(0-55 \mathrm{cal} \mathrm{kBP})$. Radiocarbon, 62 (4), 725-757. https://doi.org/10.1017/RDC.2020.41

Rimantienè, R., 1971. Paleolit i mezolit Litvy. Vilnius: Mintis.

Rimantiene, R., 1992. The Neolithic of the Eastern Baltic. Journal of world prehistory, 6 (1), 97-143. https://doi.org/10.1007/ $\underline{\text { BF00997586 }}$

Rimantienè, R., 1999. Die Kurische Nehrung aus dem blickwinkle des archäologen. Vilnius: Vilniaus dailès akademijos leidykla.

Rimkus, T., 2018. Weaponry in the Daily Life of a Hunter-Fisherman-Gatherer. In: A. Bliujienè, ed. The Klaipeda (Memel) region: from origins to the 17th century. Klaipeda: History $\mathrm{Mu}-$ seum of Lithuania Minor, pp. 139-146.

Rimkus, T., 2019. In search of Lithuania coastal Mesolithic. Review of current data and the aims of an ongoing research project. Fornvännen, 114 (1), 1-11.

Rimkus, T., Girininkas, A., 2019. Tyrimai Aukštumalos akmens amžiaus gyvenvietès bei jų aplinkoje. In: ATL 2018 metais. Vilnius: Lietuvos archeologijos draugija, pp. 44-49.

Rimkus, T., Girininkas, A., 2020. Tyrimai Aukštumalos akmens amžiaus gyvenvietese. In: ATL 2019 metais. Vilnius: Lietuvos archeologijos draugija, pp. 35-38.

Rimkus, T., Butrimas, A., Iršènas, M., Meadows, J., 2019. The Decorated Spindle-Shaped Bone Dagger from Šarnelè: the Earliest Example of Hunter-Gatherer Mobile Art in Lithuania. Archaeol. Baltica, 26, 50-62. http://dx.doi.org/10.15181/ ab.v26i0.2022

Rosentau, A., Bennike, O., Uścinowicz, S., Miotk-Szpiganowicz, G., 2017. The Baltic Sea basin. In: N.C. Flemming, J. Harf, D. Moura, A. Burges, G.N. Bailey, eds. Submerged landscape of the European Continental shelf: Quaternary paleoenvironments. Chichester: Willey-Blackwell, pp. 103-133. https://doi. org/10.1002/9781118927823.ch5

Schild, R., 1975. Późny paleolit. In: W. Chmielewski and W. Hensel, eds. Prahistoria ziem Polskich, vol. 1. Paleolit i mezolit. Wrocław: Polska Akademia Nauk, pp. 159-338.

Schild, R., 2014. Geomorphology, stratigraphy, paleoecology and radiochronology. In: R. Schild, ed. Całowanie. A Final Paleolithic and Early Mesolithic Site on an Island in the Ancient Vistula Channel. Warsaw: Polish Academy of Sciences, pp. 17-57.

Schild, R., Pazdur, M.F., Vogel, J.C., 1999. Radiochronology of the tanged point technocomplex in Poland. In: S.K. Kozłowski, J. Gurba, L.L. Zaliznyak, eds. Tanged points cultures in Europe. Read at the international archaeological symposium, Lublin, September, 13-16, 1993. Lublin: Maria Curie-Skłodowska University press, pp. 13-15.

Serwatka, K., 2018. Whats your point? Flexible projectile weapon system in the Central European Final Palaeolithic. The case of Swiderian points. Journal of Archaeological Science: Reports, 17, 263-278. https://doi.org/10.1016/j.jasrep.2017.10.048

Slah, G., 2013. Flint artefact manufacture techniques at the Palaeolithic and Mesolithic settlements at Aukštumala in Lithuania, and traceological studies of them. Archaeol. Baltica, 20, 190-199. http://dx.doi.org/10.15181/ab.v20i0.816

Šatavičius, E., 2005. Svidrų kultūra Lietuvoje. Lietuvos Arch., 29, $133-170$.
Šatavičius, E., 2012. Pasieniai 1 settlement. In: G. Zabiela, Z. Baubonis, E. Marcinkevičiūtè, eds. Archaeological Investigations in Independent Lithuania 1990-2010. Vilnius: Society of the Lithuanian Archaeology, pp. 21-26.

Tamulynas, A., 1998. Bezzenbergerio archeologiniai tyrinejimai Klaipèdos krašte. Lietuvos Arch., 15, 247-285.

Tarasenka, P., 1928. Lietuvos archeologijos medžiaga. Kaunas.

Tautavičius, A. (ed.), 1975. Lietuvos TSR archeologijos atlasas. Piliakalniai, t. II. Vilnius: Mintis.

Weber, C.A., 1902. Vegetation und entstehung des hochmoors von Augstumal im Memeldelta. Berlin: Paul Parey.

Weber, C.A., 2016. Apie Aukštumalos aukštapelkes Nemuno deltoje augalija ir vystymąsi lyginant su kitomis Žemes aukštapelkemis. Vilnius: Lietuvos gamtos fondas.

Weber, C.A., Mestorf, J., 1904. Wohnstätten de älteren neolitischen periode in der Kieler Föhrde. Berichte des SchleswigHolsteinisch-Lauenburgischen museums vaterlädischer alterthümer, 43, 9-30.

Winkler, K., 2019. Ahrensburgien und Swiderian im mittleren Oderraum. Technologische und typologische Untersuchungen an Silexartefakten der Jüngeren Dryaszeit. Untersuchungen und Materialien zur Steinzeit in Schleswig-Holstein und im Ostseeraum, band 11. Kiel/Hamburg: Wachholtz.

Zagorska, I., 2012. Senie ziemeḷbriežu mednieki Latvijā. Riga: Zinātne.

Zhilin, M., 2020. Mesolithic Bone Arrowheads as a Marker of Cultural Unity from the Baltic to Trans-Urals. Praehistoria, 1-2 (11-12), 135-148.

Zhilin, M.G., Savchenko, S.N., Nikulina, E.A., Schmölcke, U., Hartz, S., Terberger, Th., 2014. Eleven Bone Arrowheads and a Dog Coprolite - the Mesolithic Site of Beregovaya 2, Urals Region (Russia). Quartär, 61, 165-187. http://dx.doi. org/10.7485/QU61-10

Žulkus, V., Girininkas, A., 2012. Baltijos jūros krantai prieš 10 000 metu „Yoldia“. Klaipeda: Klaipèdos universiteto leidykla.

Žulkus, V., Girininkas, A., 2014. Drowned Early Mesolithic Landscapes on the Baltic Sea Bed in the Lithuanian Waters. Journal of Environmental Sciences and Engineering, 4, 274-289.

Žulkus, V., Girininkas, A., 2020. The Eastern Shores of the Baltic Sea in the Early Holocene According to Natural and Cultural Relict Data. GEO: Geography and Environment, 7 (1), 1-16, https://doi.org/10.1002/geo2.87

Žulkus, V., Girininkas, A., Stančikaitè, M., Gryguc, G., Šeirienè, V., Mažeika, J., 2015. In shores of the Yoldia Sea and Ancylus Lake. Maritime landscapes in the Lithuanian waters: multidisciplinary study. In: O. Felczak, ed. The Baltic Sea - a Mediterranean of North Europe: in the light of archaeological, historical and natural science research from Ancient to Early Medieval times. Gdańsk: Scientific Association of Polish Archaeologists, Gdańsk Division, pp. 9-18.

Žulkus, V., Jarockis, R., 2013. Vikingu laikai ir ikivalstybinis laikotarpis. Lietuvos archeologija, t. IV. Klaipeda: Klaipèdos universiteto leidykla. 
FINALINIS PALEOLITAS

LIETUVOS KRANTO ZONOJE SU TECHNOLOGINIU AUKŠTUMALOS AKMENS AMŽIAUS GYVENVIEČIŲ IŠSKYRIMU

\section{TOMAS RIMKUS, ALGIRDAS GIRININKAS}

\section{Santrauka}

Lietuvos pajūrio zonoje šiuo metu daugiausia tyrinètos vèlyvuoju mezolitu ir neolitu datuojamos gyvenvietess ir atskiri šiems laikotarpiams priskiriami radiniai. Finalinis paleolitas iki šiol čia buvo reprezentuojamas tik remiantis Aukštumalos akmens amžiaus I ir II gyvenvietemis, kurios rastos $2004 \mathrm{~m}$. Publikuota šių tyrimų archeologinè medžiaga ir jos interpretacijos neatskleide tikrosios šių gyvenviečių technologijos ir chronologijos, todèl 2018-2019 m. Aukštumalos gyvenviečiu tyrimai buvo atnaujinti. Gyvenvietes lokalizuojamos Aukštumalos aukštapelkès rytinèje dalyje, fluvioglacialinès kilmès kalvelèje (1 pav.). Per šiuos tyrimų metus ištirtas iš viso $84 \mathrm{~m}^{2}$ dydžio plotas. Be jau žinomų gyvenviečių, aptikta dar viena, kuriai suteiktas Aukštumalos akmens amžiaus III gyvenvietes pavadinimas (2 pav.). XIX a. pabaigoje ir XXa.čialokalizuojamąkalvelę aprašè vokiečių gamtininkas C. A. Weberis, kaip numanomą piliakalnị ją tyrinëjo A. Bezzenbergeris, vèliau ją minèjo ir kiti XX ir XXI a. senoviniams ịtvirtinimams skirti darbai.

2018-2019 m. tyrinèjimų laikotarpiu iš viso aptikta 311 vnt. įvairių uolienų radinių, kuriuos sudare dirbiniai, jų ruošiniai ir gamybos atliekos. Titnago žaliavos nuoskalų ir dirbinių daugiausia aptikta I gyvenvietėje (3 pav.), o tarp jų dirbinių kategorijai buvo priskirti gremžtukai, kirviai, antgaliai, perforatoriai, retušuotos nuoskalos, režtukai ir skaldytiniai (4 pav.). Daugelis aptiktų antgalių fragmentiški, jie priskiriami finalinio paleolito Svidrų kultūros technologijai ir turi karklo lapo formą (5 pav.). Kiti dirbiniai, naudoti ūkio darbams, taip pat būdingi finalinio paleolito technologijai (6 pav.). Gyvenvietėse rastos skeltès atskeltos nuo vienagalių ir dvigalių skaldytinių, daugelis jų plačios ir ilgos, degusios ir padengtos balkšva patina (7 ir 8 pav.; 2 lentelè). Titnago dirbiniu gamybai naudotas Baltijos eratinis titnagas, kurio išteklių Nemuno deltos regione nèra, o aptinkami tik pavieniai nedideli rieduliai. Netitnaginių uolienų dirbinių ir skaldymo atliekų rasta visose Aukštumalos gyvenvietėse, tačiau jų kiekiu išsiskyrè III gyvenvietè. Tarp žaliavos dominuoja granitas, kvarcas, kvarcitas, smiltainis, žerutis ir opoka (9 pav.). Šių uolienų dirbinių grupei buvo priskirtas antgalis, skeltès fragmentas, muštukas ir skaldytiniai, taip pat neidentifikuotos paskirties apskaldyti stambesni rieduliai (10 pav.).
Šiuo metu Lietuvos pajūrio zonoje žinomos trys finalinio paleolito gyvenvietes, aptiktos Aukštumaloje, jos priskiriamos Svidrų kultūrai. 2021 m. Pūzraviečių k. aptiktas pavienis šios kultūros technologijai būdingas antgalis su charakteringa ikkote (11 pav.). Tai šiuo metu vieninteliai finalinio paleolito technologijos įrodymai dabartinèje Lietuvos kranto zonoje.

Aukštumalos akmens amžiaus gyvenvietès yra smèlinio tipo gyvenvietės, kuriose aptikta medžiaga dažnai būna maišyta, be organikos radinių. Technologiniu požiūriu Aukštumaloje aptikti radiniai yra homogeniški, ir priemaišų iš kitų laikotarpių neaptikta. Smèlio sluoksniuose rasti ir datuoti degę lazdyno riešutų fragmentai bei medžio angliukai neatskleidžia realaus gyvenviečiu egzistavimo laiko (1 lentelè). Remiantis Baltijos jūros vandens lygio kaita ir Aukštumalos aukštapelkès raida, gyvenvietės turèjo egzistuoti preborealio pradžioje.

Kol kas trūksta duomenų apie atskirų Aukštumalos akmens amžiaus gyvenviečiu chronologinį ryšį ir funkciją. Tam reikalingi papildomi tyrimai. Tačiau darome prielaidą, kad III gyvenvietè galèjo būti skirta netitnaginèms uolienoms apdirbti. Prielaida daroma šioje vietovèje aptikus dideli kiekị nuoskalų, taip pat skaldytinių ir muštuką (iš viso 79 vnt.). 